\title{
Total Quality Management Pendidikan Islam (Studi TPQ Qiro'ati di Kabupaten Kudus Jawa Tengah)
}

\author{
M. Saekan Muchith \\ Manajemen Pendidikan Islam Pascasarjana IAIN Kudus Jawa Tengah \\ muhsaekan@gmail.com
}

\begin{abstract}
This research is a qualitative research which is aimed at describing the quality management of Islamic education, teachers' competencies, and examination at TPQ Qiro'ati in Kudus, Central Java. The technique of data retrieval is observation, interviews, and documentation. The data are analysed using technical domain, taxonomy and cultural theme analysis. The research results reveal that, in general, the management of the TPQ Qiro'ati is initiated from a very mature and systematic plan both from the ustadz/ustadzah recruitment aspects and a very consistent and tiered implementation and coaching program. The students'(santri) graduation process is carried out through tiered examinations from the institutional level (TPQ), subdistrict and district levels. After being declared as having passed the examination at all levels, the santri are also tested publicaly similar to a doctoral promotion test. These are the attestation of total quality management transparencyof Islamic education to the public so as to provide a greater level of trust from the community. Therefore, the management of the TPQ Qiro'ati is in accordance with the spirit of the general community dynamics which required them to be open to the public.
\end{abstract}

Keywords: Quality management, TPQ Qiro'ati, teachers' competencies, examination, Islamic education

\begin{abstract}
Abstrak
Penelitian ini adalah penelitian kualitatif yaitu bertujuan mendeskripsikan atau menggambarkan apa yang ada di lokasi penelitian, dalam hal ini manajemen mutu pendidikan Islam, kompetensi guru, dan ujian di TPQ Qiro'ati di Kudus, Jawa Tengah. Tehnik pengambilan data dilakukan dengan observasi, wawancara,dan dokumentasi. Kemudian hasil perolehan data dianalisis menggunakan teknis analisa domain, analisa taksonomi dan analisa tema budaya. Secara umum ditemukan bahwa pengelolaan TPQ Qiro'ati diawali dari perencanaan yang sangat matang dan sistematis baik dari aspek rekrutmen Ustaz/Ustadzah maupun dukungan pelaksanaan dan pembinaan program yang sangat konsisten dan berjenjang. Proses ketuntasan atau kelulusan santri dilakukan melalui ujian berjenjang dari tingkat lembaga (TPQ), tingkat kecamatan (rayon) dan kabupaten. Setelah dinyatakan lulus di semua jenjang, santri juga diuji secara terbuka sebagai layaknya ujian promosi program doktor. Seluruh tahapan tersebut menjadi wujud transparansi manajemen kepada publik sehingga memberikan tingkat kepercayaan semakin besar dari masyarakat. Apa yang dilakukan dalam pengelolaan TPQ Qiro'ati telah sesuai dengan semangat dinamika masyarakat melenial yang secara otomatis menghendaki adanya keterbukaan informasi kepada masyarakat (publik).
\end{abstract}

Kata kunci: Manajemen mutu, kompetensi guru, ujian, TPQ Qiroa'ti, pendidikan Islam

\section{A. Pendahuluan}

Pendidikan Islam merupakan subsistem pendidikan nasional (pendidikan bangsa Indonesia) yang berarti bahwa pendidikan Islam memiliki kemiripan dengan pendidikan nasional meskipun juga banyak perbedaanya. Pendidikan adalah usaha sadar dan terencana untuk mewujudkan suasana belajar dan proses pembelajaran agar peserta didik dapat secara 
aktif mengembangkan potensi dirinya untuk memiliki kekuatan spiritual keagamaan, pengendalian diri, kepribadian, kecerdasan, ahlak mulia, serta keterampilan yang diperlukan dirinya, masyarakat, bangsa dan negara ${ }^{1}$. Pendidikan Islam sebagai subsistem dari pendidikan nasional merupakan bagian integral dari pendidikan nasional yang memiliki proses, tujuan dan target yang lebih spesifik dalam hal yang terkait dengan perintah dan larangan Allah swt sehingga menjadi kualitas manusia seutuhnya.

Keunggulan pendidikan Islam, jika dibandingkan dengan pendidikan nasional Indonesia maupun pendidikan barat, dapat dilihat dari berbagai aspek antara lain: pertama, pendidikan Islam adalah pendidikan yang menekankan kepada pentingnya pembentukan manusia seutuhnya yang menitikberatkan pada pengembangan akal dan hatinya, rohani dan jasmaninya, ahlaq dan keterampilannya. Pendidikan Islam memiliki ruang lingkup yang sangat kompleks dan menyangkut berbagai aspek sehingga sangat sulit dijangkau atau dicapai tujuan atau targetnya. Oleh sebab itu pendidikan Islam merupakan proses yang tiada henti atau berakhir ${ }^{2}$.

Kedua, pendidikan Islam adalah proses bimbingan jasmani dan rohani berdasarkan hukum-hukum Islam menuju terbentuknya kepribadian utama menurut Islam. Pendidikan Islam mengandung makna proses mengarahkan orang lain sesuai aturan yang berlaku sehingga terbentuk kualitas kepribadian sesuai norma-norma Islam. Pendidikan Islam lebih diarahkan sesuai dengan ketentuan norma Islam dalam Alqur'an dan hadis. Pendidikan berarti pendidikan yang sesuai dengan norma Islam $^{3}$.

Ketiga, perbedaan pendidikan Islam dan pendidikan barat dapat dilihat dari 2 (dua) perbedaan yaitu: (1) dari aspek muatan materi/substansi materi yang diajarkan. Pendidikan Islam setidaknya menyangkut tiga macam substansi materi yaitu tarbiyah, ta'lim dan ta'dib. Tarbiyah lebih menekankan pada optimalisasi kecerdasan intelektual (kognitif) yaitu upaya untuk membimbing peserta didik agar memiliki kualitas intelektualitas atau optimalisasi pengembangan rasio/akal pikiran. Ta'lim merupakan proses pendidikan yang menekankan pembentukan sikap, etika atau moral kepribadian dalam hubungannya dengan sesama manusia dan dengan lingkungan. Ta'dib adalah proses pendidikan yang menekankan pentingnya mengenal dan memahami kekuatan di luar manusia yaitu adanya Allah swt. Pendidikan barat tidak akan mengajarkan ketiga aspek tersebut, pendidikan barat mayoritas hanya optimalisasi intelektual (kognitif/tarbiyah) saja, (2) dari aspek epistimologi. Pendidikan Islam dalam menemukan kebenaran dimulai dari posisi wahyu (Al qur'an dan hadis) kemudian akal pikiran dan realitas. Dengan kata lain, epistemologi pendidikan Islam memiliki jenjang wahyu, akal/pikiran, realitas/empirik. Sedangkan pendidikan barat berangkat dari kekuatan akal pikiran dan empirik.

Dilihat dari aspek idealitas, pendidikan memiliki tujuan yang sangat mulia karena secara prediktif pendidikan Islam mampu melahirkan kualitas orang yang memiliki keterampilan (skill) secara utuh sehingga memiliki kemampuan untuk bertahan hidup dalam menghadapi problematika kehidupan sosial. Mengapa demikaian? Pendidikan Islam melatih dan membimbing manusia memiliki kesiapan hidup di dunia dan akhirat sehingga akan mampu menjadi manusia yang bahagia di dunia dan akherat sesuai dengan doa yang dipanjatkan setiap hari "Robbana aatina fil dunya hasanah, wafi al akherati hasanah, waqina adza ba al naar".

\footnotetext{
${ }^{1}$ Undang Undang Sistem Pendidikan Nasional (UUSPN) Nomor 20 tahun 2003, Pasal 1 ayat 1, dalam Undan-Undang tersebut secara jelas bahwa pendidikan nasional memiliki target mengembangkan potensi berupa keterampilan spiritual keagamaan. Dapat dikatakan bahwa pendidikan keagamaan (Islam) memiliki peran sangat penting dalam konteks sistem pendidikan nasional bangsa Indonesia.

${ }^{2}$ Azumardi Azra, Pendidikan Islam: Tradisi dan Moderenisasi Menuju Milenium Baru, (Jakarta: Logis Wacana ilmu), 1998, h. 32.

${ }^{3}$ Ahmad D Marimba, Pengantar Filsafat Pendidikan Islam, (Bandung, Jawa Barat: Maarif), 1989, h.7.
} 
Idealitas pendidikan Islam belum sepenuhnya sesuai harapan. Secara empiris pendidikan Islam justru mengalami banyak kelemahan yang muncul dari kalangan umat Islam sendiri. Dilihat dari perspektif materi, pendidikan Islam masih dipahami sebagai proses pendidikan yang hanya mengajarkan cara membaca dan menulis Al qur'an dan mengajarkan hafalan doa-doa ibadah pokok (mahdhah). Istilah lainnya di sebut "ngaji" yaitu belajar membaca dan menulis Al qur'an. Dari perspektif manajerial, pendidikan Islam dikelola asalasalan sehingga tidak tertib administrasi. Pengelolaan atau manajemen pendidikan Islam masih bertumpu pada asumsi keihlasan yang sempit sehingga pasrah tanpa dibarengi dengan pertimbangan rasionalitas. Bekerja di lembaga pendidikan Islam dilandasi dengan karena Allah (lillahi ta'ala) yang tidak didukung dengan langkah-langkah rasional. Masih banyak masyarakat (umat Islam) yang memiliki persepsi "miring" dan "rendah" terhadap kualitas lulusan dan kualitas pengelolaan pendidikan Islam. Dari perspektif dukungan dana (biaya), ada asumsi bahwa pendidikan tidak boleh dengan biaya mahal. Umat Islam itu sendiri yang seringkali memiliki kepribadian ganda, satu sisi menilai wajar untuk mengeluarkan biaya tinggi dalam pendidikan musik, olahraga, tetapi di sisi lain tidak mau mengeluarkan biaya tinggi untuk pendidikan Islam. Sikap kepribadian ini merupakan ironi tersendiri bagi pengelolaan dan pengembangan pendidikan Islam, sehingga menyebabkan sulitnya pendidikan Islam berkembanag setara dengan pendidikan lainnya.

Pendidikan di Indonesia terdiri dari pendidikan formal dan nonformal. Pendidikan Islam juga memiliki dua jenis yaitu pendidikan Islam formal seperti Madrasah Ibtidaiyah (MI/SD), Madrasah Tsanawiyah (MTS/SMP) dan Madraah Aliyah (MA/SMA/SMK). Sedangkan pendidikan Islam nonformal adalah Madrasah Diniyah dan Taman Pendidikan Al Qur'an (TPQ). Kabupaten Kudus Jawa Tengah dikenal dengan kota santri. Salah satu cirinya memiliki lembaga pendidikan Islamnon formal dan pondok pesantren terbanyak di banding wilayah lain di Jawa Tengah. Sampai tahun 2018 Kabupaten Kudus memiliki 86 pondok pesantren, 1050 Taman Pendidikan Al Qur'an (TPQ) dan 310 Madrasah Diniyah (Madin). Diantara lembaga pendididikan Islam tersebut terdapat TPQ dengan metode pembelajaran Qiro'ati sebanyak 360 lembaga. Pembelajaran pendidikan TPQ memiliki metode yang berbeda-beda, sebagian TPQ ada yang menggunakan metode Iqra, metode Yanbu'a dan metode Qiro'ati. Metode Qiro'ati adalah proses membelajarkan Al qur'an yang berdasarkan/menggunakan buku Qiro'ati yang disusun oleh KH. Ahmad Dachlan Salim Zarkasyi. Dengan metode Qiro'ati tersebut, maka akhirnya TPQnya juga disebut TPQ Qiro'ati. Praktik pembelajaran TPQ metode Qiro'ati memiliki perbedaan dengan TPQ metode selain Qiro'ati. Perbedaannya terdapat pada beberapa hal berikut: 1) Memiliki kesinambungan antara halaman satu dengan halaman berikutnya, 2) Memiliki kesinambungan antara jilid satu dengan jilid seterusnya, 3) Disesuaikan dengan usia anak yang belajar Al qur'an, 4) Contoh kata dan kalimatnya bersumber dari ayat-ayat dalam Al qur'an, 5) Setiap pokok bahasan atau materi sudah secara otomatis menerapkan tajwid, dan 6) Dilengkapi petunjuk mengajar di setiap pokok bahasan ${ }^{4}$.

Keunikan yang dimiliki TPQ Qiro'ati akan memberikan banyak manfaat untuk pengembangan mutu kelembagaan pendidikan Islam jika dikaji, diteliti dan disosialisasikan secara ilmiah. Dengan kajian, penelitian dan publikasi, masyarakat akan mudah mengetahui secara rasional dan obyektif tentang berbagai inovasi yang dilakukan oleh TPQ dengan metode pembelajaran Qiro'ati. Penelitian ini didasarkan pada 5 (lima) rumusan masalah yaitu:

1. Seperti apa konsep mutu yang dipahami oleh para pengelola TPQ metode Qiro'ati?

${ }^{4}$ Disarikan dari http://www.Qiro'atipusat.or.id, diunduh pada tanggal 21 Juni 2018. Dalam web tersebut juga banyak dijelaskan berbagai hal yang terkait dengan keunikan TPQ dengan metode Qiro'ati. 
2. Apa saja nilai-nilai mutu pendidikan Islam yang ada di dalam proses pembelajaran TPQ metode Qiro'ati?

3. Bagaimana nilai-nilai mutu pendidikan Islam diterapkan di dalam pembinaan kualifikasi dan kompetensi guru TPQ metode Qiro'ati?

4. Bagaimana nilai-nilai mutu pendidikan Islam diterapkan dalam proses ujian bagi peserta didik TPQ metode Qiro'ati?

5. Bagaimana nilai-nilai mutu pendidikan Islam yang ada di dalam pengembangan kelembagaan TPQ metode Qiro'ati?

Penelitian ini menggunakan pendekatan deskriptif kualitatif, yaitu penelitian yang mendeskripsikan atau menggambarkan apa yang ada di lokasi penelitian. Penelitian dengan metode kualitatif adalah penelitian yang bertujuan menghasilkan data deskriptif berupa katakata tertulis atau lisan dari orang-orang dan perilaku yang diamati ${ }^{5}$. Penelitian ini didukung data yang valid dan reliable, oleh sebab itu pengambilan data penelitian ini digunakan dengan beberapa cara antara lain: pertama, metode observasi yaitu proses melakukan pengamatan sikap dan perilaku yang terjadi di lokasi penelitian. Metode ini dimaksudkan untuk mengetahui berbagai fenomena yang terjadi tentang manajemen mutu lembaga pendidikan di TPQ Qiro'ati Kabupaten Kudus, Jawa Tengah. Kedua, metode wawancara, yaitu proses melakukan dialog atau memberikan pertanyaan kepada pihak yang dianggap memiliki kewenangan dan sesuai dengan tema penelitian. Wawancara dilakukan kepada para pengurus TPQ Qiro'ati yang ada di Kabupaten Kudus Jawa Tengah, beberapa kepala TPQ Qiro'ati dan perwakilan para guru/ustad/ustadzah yang menjalanakn tugas di TPQ Qiro'ati di kabupaten Kudus, Jawa Tengah.

Metode dokumentasi yaitu proses mengumpulkan dokumen atau data tertulis tentang kelembagaan atau organisasi TPQ Qiro'ati. Dokumentasi tentang manajemen mutu TPQ Qiro'ati diperoleh dari pengurus pusat, wilayah ataupun daerah. Dokumentasi ini dipergunakan untuk memperkuat atau mendukung data penelitian yang diperoleh peneliti melalui metode observasi dan wawanacara. Data yang diperoleh melalui metode tersebut, kemudian analisis secara detail sehingga peneliti dapat menemukan makna di balik data yang terjadi dilapangan/lokasi penelitian. Analisa data penelitian ini menggunakan metode analisis data versi Spradly yang dikutip oleh Sugiyono yaitu analisis data yang dilakukan dengan empat tahap, yaitu analisa domain, analisa taksonomi, analisa komponensial dan analisa tema budaya.

Analisa domain dilakukan untuk melakukan pemaknaan data secara umum tentang manajemen mutu yang dilaksanakan di TPQ Qiro'ati di Kabupaten Kudus, Jawa Tengah. Analisa domain ini sebagai tahapan analisa awal untuk mengetahui gambaran umum tentang fokus penelitian yang telah ditetapkan oleh peneliti. Analisa taksonomi dilakukan untuk melakukan pemaknaan data berdasarkan kategori yang telah ditentukan oleh peneliti. Kategori yang ditentukan adalah kategori persepsi mutu dari pengelola TPQ Qiro'ati, kategori nilai-nilai mutu dalam proses pembelajaran, kategori nilai-nilai dalam kompetensi tenaga pendidik dan nilai-nilai pengembangan kelembagaan. Analisa komponensial dilakukan untuk menemukan keunikan atau spesifik dari masing masing kategori yang telah ditentukan. Analisa komponensial ini untuk menemukan spesifikasi dari persepsi mutu dari pengelola, menemukan spesifikasi proses pembelajaran, kualifikasi tenaga pendidik dan pengembangan kelembagaan yang telah dan akan dilakukan. Analisa tema budaya (kultural) dimaksudkan untuk menemukan hubungan atau keterkaitan antara apa yang ada di lokasi penelitian dan teori yang ada. Analisa tema budaya ini menemukan makna tentang manajemen mutu secara keseluruhan yang dilakukan di TPQ Qiro'ati sehingga dapat dipublikasikan kepada publik. 1995, h.15.

${ }^{5}$ Lexy J Moleong, Metode Penelitiaan Kualitatif, (Bandung Jawa Barat: PT. Remaja Rosdakarya), 
Dengan empat tahapan analisa data ini, penelitian ini menemukan gambaran nyata tentang menejemen mutu di lembaga pendidikan Islam khususnya yang dilaksanakan di TPQ metode Qiro'ati yang ada di kabupaten Kudus, Jepara, Pati dan Demak, Jawa Tengah. Selain itu, data dan analisa data harus dipastikan validitas dan reabilitasnya. Untuk menjaga akurasi data (validitas dan reabilitas data) maka peneliti melakukan langkah-langkah sebagai berikut: pertama, perpanjangan pengamatan. Observasi atau pengamatan yang dilakukan peneliti tidak cukup hanya sekali atau dua kali dan dengan durasi waktu yang singkat. Pengamatan dilakukan secara berulang-ulang dan dalam durasi waktu yang lama, minimal 30-60 menit. Hal ini dimaksudkan untuk memperoleh data yang valid dan realiabel. Kedua, triangulasi yaitu peneliti akan melakukan croscek data atau informasi kepada pihak-pihak yang memiliki kewenangan dan sesuai dnegan tema penelitian. Triangulasi ini dimaksudkan agar data hasil wawancara benar benar terjadi akurasinya.

Penelitian ini berfokus pada manajemen mutu pendidikan Islam. Mutu memiliki makna dan ruang lingkup sangat luas, sehingga tidak mungkin semua aspek dalam mutu dikaji oleh peneliti. Manajemen dalam penelitian ini memiliki makna proses mempertahankan dan meningkatkan sesuatu secara rutin, sistematis dan komprehensif sehingga dapat dicapai apa yang telah ditentukan. Mutu dalam penelitian ini memiliki makna sedikitnya dua hal, yaitu mutu dalam artian suatu proses yang memiliki nilai tambah atau keunikan bagi elemen lain. Aspek kedua mutu dalam penelitian ini adalah aktivitas sesuai dengan kreteria yang telah ditetapkan. Manajemen mutu dalam penelitian ini adalah proses mempertahankan dan meningkatkan proses yang sesuai kreteria yang ditentukan lembaga pendidikan Islam (TPQ Qiro'ati) yang meliputi aspek mutu proses pembelajaran, mutu tenaga pendidik (Ustadz/Ustadzah), mutu proses tes atau ujian akhir dan mutu dalam pengembangan kelembagaan yang telah dan akan dilakukan.

Setiap lembaga termasuk lembaga pendidikan Islam khususnya Taman Pendidikan Al Qur'an (TPQ) yang menggunakan metode Qiro'ati (atau disingkat TPQ Qiro'ati) juga mendambakan mutu dalam perencanaan, proses maupun hasil (output) serta mutu pengembangan kelembagaan. Edward Salis ${ }^{6}$ dalam buku Total Quality Management in Education menjelaskan bahwa dalam mutu menyangkut berbagai aspek dan memiliki ruanglingkup sangat luas. Mutu menyangkut tentang proses, hasil, sarana dan termasuk kultur atau budaya organisasi. Oleh sebab itu mutu bisa berupa sistem atau norma, produk perilaku maupun produk barang dan/atau jasa. Taman pendidikan Al Qur'an (TPQ) Qiro'ati merupakan suatu lembaga pendidikan Islam yang memiliki tugas dan tanggung jawab melakukan proses, melahirkan produk berupa produk barang (manusia) dan jasa ( sikap dan kepribadian yang dilakukan manusia).

Edward Deming menjelaskan bahwa mutu adalah terkait dengan kesenangan atau kecocokan pelanggan ${ }^{7}$. Sesuatu dikatakan memenuhi kriteria mutu jika pelanggan atau masyarakat banyak yang merasa cocok atau senang terhadap proses dan produk dari perusahaan. Mutu dalam konteks ini selalu dilihat dari sejauh mana masyarakat sebagai pelanggan memiliki kesenangan terhadap proses maupun produk yang dihasilkan perusahaan. Semakin banyak masyarakat senang semakin tinggi/besar mutu yang akan diperoleh, sebaliknya semakin sedikit masyarakat yang senang maka semakin kecil peluang untuk meraih mutu. JM Juran menjelaskan bahwa mutu adalah proses yang memiliki keunikan atau ketertarikan bagi pelaku maupun orang lain. Dalam konteks ini, mutu dilihat atau diukur sejauh mana proses yang dilakukan perusahaan memiliki keunikan atau nilai tambah dibanding

\footnotetext{
${ }^{6}$ Edward Salis, Total Quality Management, (Daerah Istimewa Yogyakarta: Ircisod), 2007, hal : 225.

${ }^{7}$ Edward W Deming, Out of the Crisis: Quality, Productivity and Competitive Position, (Cambridge: Cambridge University Press), 1986.
} 
lainnya ${ }^{8}$. Philip B Crosby menjelaskan bahwa mutu adalah proses yang dilakukan di suatu perusahaan sesuai dengan kriteria yang ditentukan atau tidak ${ }^{9}$. Dalam konteks ini, mutu dilihat atau diukur dari aspek sejauh mana proses dan hasil itu sesuai dengan kreteria atau ketentuan yang telah ditetapkan.

Dilihat dari spek teoritis dan praktis, penelitian ini memiliki beberapa manfaat sebagai berikut: 1) Manfaat Teoritis. Penelitian ini memiliki manfaat teoritis untuk menambah khazanah ilmu pengetahuan atau informasi tentang pendidikan Islam khususnya wacana mutu pendidikan Islam yang dipraktikkan di Taman Pendidikan Al Qur'an (TPQ) metode Qiro'ati, dan 2) Manfaat Praktis. Penelitian ini memiliki manfaat praktis bagi beberapa elemen, antara lain: a) Manfaat bagi pengelola TPQ metode Qiro'ati: penelitian dapat dijadikan bahan pengembangan manajerial untuk di masa mendatang, sehingga TPQ metode Qiro'ati semakin mampu mempertahkan dan meningkatkan mutunya secara optimal, b) Manfaat bagi tenaga pengajar: penelitian ini dapat dijadikan bahan evaluasi dan peningkatan ketrampilan para guru dalam melaksanakan pembelajaran di TPQ metode Qiro'ati, c) Manfaat bagi masyarakat: penelitian ini dapat dijadikan tambahan informasi bagi masyarakat, sehingga masyarakat memiliki pengetahuan secara utuh tentang TPQ metode Qiro'ati, dan d) Manfaat bagi peneliti; penelitian ini dapat dijadikan bahan pengayaan atau tembahan pengalaman bagi peneliti sehingga di waktu mendatang akan lebih bermutu dalam melakukan penelitian.

\section{B. Sejarah Singkat TPQ Qiro'ati}

Kehadiran TPQ Qiro'ati diawali dari keresahan, ketidakpuasan dan juga keprihatinan Almarhum KH. Dachlan Salim Zarkasyi ketika melihat proses belajar mengajar Al Qur'an di madrasah, mushalla, masjid dan lembaga masyarakat muslim pada umumnya. Dalam pandangan beliau, ternyata masih banyak masyarakat yang belum dapat membaca Al Qur'an dengan baik dan benar, apa lagi dilihat dari kualitas tajwidnya. Oleh sebab itu perlu adanya panduan, bimbingan dan pembelajaran yang intensif dan sistematis. Keresahan itulah yang mendorong Almarhum KH Dachlan Salim Zarkasyi pada tahun 1963 memulai menyusun metode baca tulis Al Qur'an yang sangat praktis. Berkat usaha yang gigih dan atas rida Allah SWT, akhirnya KH Dachlan Salim Zarkasyi berhasil menyusun sepuluh jilid yang dikemas sangat sederhana. Almarhum KH Dachlan Salim Zarkasyi dalam perjalanan menyusun metode baca tulis Al Qur'an sering melakukan studi banding keberbagai pesantren dan madrasah Al Qur'an dan sampai ke Pondok Pesantren Mambaul Hisan Sidayu Gresik Jawa Timur (tepatnya pada bulan Mei 1986) yang pada saat itu dipimpin oleh Almukarram KH Muhammad.

Selama proses penyusunan buku atau kitab sebanyak sepuluh jilid, Almarhum KH Dachlan Salim Zarkasyi rajin melakukan studi banding atau silaturrahmi. Hal ini dimaksudkan untuk memperoleh informasi dan data yang sempurna sehingga buku yang ditulis akan memiliki kontribusi besar dalam pembelajaran TPQ Qiro'ati. Banyak lokasi yang dituju untuk menjalin kerjasama atau silaturrahmi diantaranya Pesantren Sedayu Gresik yang memiliki santri berusia 4-6 tahun. Menurut KH Muhammad, Pondok Pesantren yang dipimpinnya telah dirintis sejak tahun 1965 dengan jumlah murid sebanyak 1300 orang siswa yang datang dari berbagai kepulauan yang ada di Indonesia. Selain berkunjung ke berbagai pondok pesantren dan TPQ, akhirnya Almarhum KH Dachlan Salim Zarkasyi memutuskan untuk mendirikan TPQ Al Qur'an sekaligus mempraktikan dan menguji metode yang diciptakan. Tepat pada tanggal 1 Juli 1986, Almarhum KH Dachlan Salim Zarkasyi resmi membuka atau mendirikan TK Al qur'an dengan metode pembelajaran Qiro'ati yang disusun sendiri. Berkat Inayah Allah SWT, diluar dugaan dalam perjalanan 7 bulan ada beberapa siswa yang telah mampu membaca

\footnotetext{
${ }^{8}$ Joseph M Juran, Quality Handbook, (New York: McGraw Hill), 1988.

${ }^{9}$ Philip B Crosby, Quality is Free, (USA: New American Library), 1980.
} 
beberapa ayat Al Qur-an serta dalam jangka 2 tahun telah menghatamkan Al Qur'an dan mampu membaca dengan baik dan benar (bertajwid).

Akibat kualitas metode pembelajaran yang diciptakannya, TK Al Qur'an yang dipimpinnya makin dikenal masyarakat dari berbagai pelosok wilayah Jawa Tengah. Dari keberhasilan inilah banyak yang melakukan studi banding dan meminta petunjuk cara mengajarkan metode yang diciptakannya. KH Dachlan Salim Zarkasyi terus menerus melakukan evaluasi dan meminta penilaian dari para Kyai Al Qur'an atas motode yang diciptakannya. Atas usul dari Ustadz A. Djoned dan Ustadz Syukri Taufiq, metode ini diberi istilah dengan nama "QIROATI" yang artinya BACAANKU (pada saat itu ada 10 jilid) ${ }^{10}$.

Pengelolaan TPQ metode Qiro'ati memiliki keunikan dalam proses pembelajaran, pembinaan guru/ustadz dan sistem evaluasi tahap akhir. Keunikan tersebut tidak dilakukan oleh pendidikan lainnya meskipun pendidikan formal di semua jenjang. Ditengah-tengah problem internal pendidikan Islam khususnya dukungan dana dan persepsi masyarakat, TPQ dengan metode Qiro'ati tetap eksis bahkan semakin berkembang dalam pengelolaan dan peningkatan kualitas dalam proses pembelajaran, kualifikasi tenaga pengajar (ustadz/ustadzah) dan kualitas lulusan. Secara umum dapat digambarkan pengelolaan dan peningkatan mutu TPQ metode Qiro'ati sebagai berikut: Pertama, pola pembelajaran menggunakan pola tematik dan dikelompok berdasarkan jenjang atau jilid, sehingga peserta didik sangat mudah untuk memahami pelajaran yang disampaikan. Langkah ini merupakan proses untuk mempertahankan dan meningkat mutu proses pembelajaran. Peserta dididk mengetahui secara jelas tahapan materi yang akan dipelajari, sehingga siswa bisa belajar sebelumnya. Dari pola seperti inilah maka peserta dididk cepat untuk mengenal dan membaca al qur' an secara fasih sesuai dengan ketentuan tatabahasa (tajwid).

Kedua, kualifikasi tenaga pengajar. TPQ dengan metode Qiro'ati selalu menjaga kualitas membaca Al Qur'an (kefasihan) dan kemampuan mengajarkan Al Qur'an dengan metode Qiro'ati. Hal ini dilihat dari adanya organsiasi yang dibentuk untuk membina kemampuan membaca Al Qur'an dan ketrampilan mengajarkan Al Qur'an yang sesuai dengan metode Qiro'ati yaitu adanya Lembaga Pengajar Guru Qiro'ati (LPGQ) yang melakukan pertemuan secara rutin bulanan. Ketiga, kompetensi tenaga pengajar. TPQ metode Qiro'ati memiliki ketentuan untuk mempertahankan dan meningkatkan kompetensi para tenaga pengajar. Semua tenaga pengajar di TPQ metode Qiro'ati harus lulus dan bersertifikat yang dikeluarkan pengurus Qiro'ati di tiap-tiap kabupaten. Guru atau tenaga pengajar yang belkum memiliki sertifikat lulus fasih membaca alqur'an versi Qiro'ati tidak diperbolehkan mengajarakn Qiro'ati di TPQ metode Qiro'ati. Setiap tiga bulan sekali, seluruh tenaga pengajar di lakukan pengetesan kemampuan membaca Al Qur'an, untuk diketahui kualitas kefasihan membaca Al Qur'an, jika tenaga pengajar mengalami kemunduran atau penurunan kualitas kefasihan, maka tidak diperbolehkan mengajar di TPQ metode Qiro'ati.

Keempat, metode ujian akhir. TPQ metode Qiro'ati, menerapkan sistem ujian akhir secara bertahap, yaitu ujian dihadapan penguji, di tingkat lokal lembaga TPQ dan di tingkat kecamatan. Sehingga peserta didik hanya dapat dinyatakan lulus jika mereka telah lulus dalam ujian lokal tingkat TPQ dan ujian di tingkat kecamatan. Tahap akhir, peserta didik harus dites atau diuji secara terbuka di hadapan masyarakat umum yang hadir dalam proses wisuda.

Berdasarkan gambaran umum tersebut diatas, TPQ metode Qiro'ati memiliki sistem yang baku untuk menerapakan dan meningkatkan mutu secara utuh dan kompreehnsif, mulai dari sistem seleksi, sistem pembelajaran dan sistem ujian serta sistem kualifikasi dan

${ }^{10}$ Disarikan dari http://www.Qiro'atipusat.or.id, diunduh pada tanggal 21 juni 2018), kata bacaanku mengandung filosofi bahwa TPQ Qiro'ati akan menjadi bacaan yang melekat dalam setiap santri, sehingga alqur'an benar benar selalu melekat dalam diri setiap santri TPQ Qiro'ati. Melekat tidak cukup hanya dihafal dan dibaca secara baik dan benar, melainkan benar benar dapat dipraktikan dalam realitas kehidupan sosial. 
kompetensi tenaga pengajar. Keunikan yang dilaksanakan TPQ metode Qiro'ati perlu dikembangkan dan keketahui masyarakat umum agar apa yang diterapkan di TPQ metode Qiro'ati dapat dilakukan juga di lembaga pendidikan lain baik pendidikan formal maupun nonformal.

\section{Mutu Menurut Pandangan Pengelola TPQ Qiro'ati}

Secara umum mutu dipahami sesuatu yang sesuai harapan. Apa yang diharapkan bisa menjadi keinginan itu bagian dari mutu. Mutu juga dipahami sesuatu yang terbaik bag manusia. Hal ini sesuai Firman Allah dalam Al Qur'an Surah Ali Imran ayat 110 " Kamu adalah umat yang terbaik yang dilahirkan untuk manusia. Menyuruh kepada yang ma'ruf dan mencegah kepada yang mungkar dan beriman kepada Allah “. Berdasarkan ayat ini, dijelaskan bahwa manusia yang bermutu adalah yang mau dan mampu atau berkomitmen untuk mengajak kepada kebaikan/kebenaraan dan mencegah atau mengingatkan kepada keburukan/kejahatan. Target akhir yang diperoleh adalah terwujudnya komitmen mempertahankan dan terus mengembangkan keimanan kepada Allah swt.

Para pengelola TPQ Qiro'ati memahami bahwa mutu adalah sesuatu yang dekat atau melekat dalam masyarakat. Artinya apa yang dianggap baik oleh masyarakat maka dianggap baik oleh TPQ Qiro'ati. Proses pengelolaan dan pembelajaran selalu diorientasikan untuk memenuhi anggapan masyarakat tentang kebaikan dan kualitas. Tugas utama para pengelola TPQ Qiro'ati tidak cukup memberikan pesan atau janji melainkan harus benar-benar mampu memberikan bukti-bukti yang bisa memebrikan atau meyakinkan masyarakat. Berdasarkan informasi dari Koordinator TPQ Qiro'ati Kabupaten Kudus ${ }^{11}$ dikatakan bahwa:

"Pendiri TPQ Qiroati Almarhum KH Dachlan Salim Zarkasyi, selalu mengatakan bahwa masyarakat pada hakekatnya tidak butuh janji janji tetapi lebih membutuhkan bukti. Kami yakin masyarakat secara pelan pelan akan semakin banyak yang tertarik kepada TPQ qiroati setelah mengetahui mutu lulusan dari TPQ Qiroati. Langkah kami tidak terlalu rumit yaitu dengan cara menunjukkan kepada masyarakat tentang kualitas lulusan atau hasil TPQ Qiroati yaitu dengan cara pada saat ujian /Imtas dipublikasikan di hadapan masyarakat dengan diuji oleh guru atau tim dari kecamatan dengan disaksikan banyak orang (masyarakat)."

Hal yang sama dikatakan KH. Halimi, bahwa mutu bagi TPQ Qiro'ati adalah masyarakat. Karena TPQ Qiro'ati dan juga TPQ lainya memiliki "ruh" pesantren dan komitmenya adalah meneruskan perjuangan para ulama dan kyai. Melalui wawancara tanggal 10 April 2017, dikatakan:

“Ruh TPQ Qiro'ati adalah pesantren dan Kiai, oleh sebab itu kami harus selalu mengikuti apa yang telah dilakukan para ulama dan kiai. Apa yang di cintai Kiai?, menurtu saya yang sangat dicintai Kiai dan yang selalu didekati Kiai adlaah masyarakat, karena para kiai memiliki tugas mulia mengajak untuk meningkatkan keimanan kepada Allah swt”.

Pandangan atau konsep mutu menurut pengelola TPQ Qiro'ati sejalan dengan konsep mutu menurut Edward Deming, dimana mutu diartikan kesesuaian dengan kepuasan pelanggan (masyarakat). Mutu dianggap terwujud jika masyarakat atau pelanggan merasa puas dengan proses dan produk yang dilakukan suatu perusahaan/lembaga. Jika diterapkan dalam dunia pendidikan Islam, mutu pendidikan Islam dianggap terwujud jika masyarakat memberikan

${ }^{11}$ Wawancara dengan KH Mustain Yanis, Koordinator TPQ Qiro'ati tingkat Kabupaten Kudus di rumahnya pada tanggal 22 Maret 2017. Dalam pandangan KH. Musta'in Yanis, mutu itu sebenarnya apa yang diinginkan masyarakat. Setiap pendidikan yang bisa memberikan jaminan dan kepastian atau kemantapan masyarakat terhadap proses dan hasil itu sudah termasuk pendidikan yang bermutu. Masih dalam pandangan KH. Mustain Yanis, Mutu pendidikan di TPQ yang dibilang gampang ya gampang, dibilang sulit ya sulit. 
kepercayaan kepada lembaga dengan cara berbondong-bondong mengirim putra putrinya untuk menuntut ilmu di lembaga pendidikan. Dengan demikian, TPQ Qiro'ati dikatakan bermutu jika masyarakat lebih banyak mengirim putra-putrinya untuk menuntut ilmu di TPQ Qiro'ati.

\section{Proses Pembelajaran TPQ Metode Qiro'ati}

Menurut logika pendididikan sebagai sebuah sistem, mutu atau keberhasilan ditentukan oleh berbagai aspek dimana masing-masing aspek memiliki peran yang berbeda satu dangan lainnya. Aspek pembelajaran memiliki peran sangat signifikan dibanding dengan aspek lainnya. Hal didasarkan asumsi bahwa pembelajaran adalah suasana dimana berbagai aspek saling bertemu untuk saling mempengaruhi. Pembelajaran adalah proses interaksi peserta didik dengan pendidik dan sumber belajar pada suatu lingkungan belajar (UU nomor 20 tahun 2003 pasal 1 ayat 20). Para pengelola TPQ Qiro'ati menyadari bahwa proses pembelajaran memiliki peran sangat besar dalam meraih kualitas seperti yang diharapkan. Perhatian terhadap proses pembelajaran sangat besar dalam rangka mencapai mutu yang diharapkan. Konsistensi dalam menentukan syarat kualifikasi dan kompetensi sangat besar, sehingga semua ustadz/ustadzah harus benar-benar mampu mempertahankan dan mengembangkan kualifiaksi dan kompetensi yang dipersyaratakan agar bisa tetap terus menjadi ustadz/ustadzah di TPQ Qiro'ati.

TPQ Qiro'ati menaruh perhatian besar dalam hal konsistensi kepemilikan kualifikasi dan kompetensi para ustadz/ustadzahnya ${ }^{12}$. TPQ Qiro'ati memiliki standar kualifikasi dan semua Ustadz/Ustadzah wajib memiliki sertifikat (syahadah) yang dikeluarkan Qiro'ati setelah mengikuti pelatihan dalam waktu tertentu dan dinyatakan lulus dan layak sebagai ustadz/ustadzah di TPQ Qiro'ati, seperti data berikut:

"Kami punya ketentuan pak, semua Ustadz dan Ustadzah yang mengajara di TPQ Qiroati, wajib lulus pendidikan dan pelatihan sebagai Guru TPQ Qiroati yang dinyatakan dengan perolehan setitikat atau biasa di sebut syahadah. Tidak peduli itu sarjana (S1) atau Pascasarjana, kalau ingin melamar menjadi Ustadz/Ustadzah di TPQ Qiroati ya dites dulu, untuk diketahui kemampuan atau kelayakan menjadi Ustadz/Ustadzah. Jadi tidak asal terima (rekrut) Ustadz/Ustadzah" (wawancara tanggal 26 Maret 2017).

Pembelajaran adalah proses interaksi peserta didik dengan pendidik dan sumber belajar pada suatu lingkungan belajar (UU No 20 tahun 2003, pasal 1 ayat 20). Para pengelola TPQ Qiro'ati memandang bahwa proses pembelajaran memiliki arti sangat penting dalam melahirkan mutu pendidikan, artinya semakin berkualitas dalamproses pembelajaran akan semakin besar peleuang kualitas pendidikan. Berdasarkan rumusan undang-undang sistem pendidikan inilah, para pengelola TPQ Qiro'ati memiliki perhatian dan komitmen tinggi dalam proses pembelajaran.

Berdasarkan Focus Group Discussion (FGD) bersama ustadz/ustadzah dan pengelola TPQ Kecamatan Bae Kabupaten Kudus pada bulan Oktober 2017, diperoleh beberapa hal sebagai berikut: pertama, kualitas ustadz/ustadzah sangat menentukan kualitas pembelajaran dan pendidikan. Oleh sebab itu para ustadz/ustadzah TPQ Qiro'ati harus benar-benar memiliki kualifiaksi dan kompetensi sesuai yang ditentukan. Kualifikasi ustadz/ustadzah harus memiliki syahadah (sertifikat) dari pengelola TPQ yang diperoleh melalui pelatihan. Untuk memperoleh syahadah ditempuh dalam kurun waktu yang bervariasi, ada yang mencapai 3 tahun bahkan 4

${ }^{12}$ Wawancara dengan KH. Musta'in Yanis di rumahnya tanggal 26 maret 2017. Setelah dijelaskan panjang lebar tentang kompetensi dan kualifikasi Ustadz/Ustadzah TPQ Qiro'ati, Sambil berkelakar peneliti berkomentar “ kalau begini, guru TPQ Qiro'ati lebih berat disbanding jadi Guru atau Dosen Kiai, karena kompetensi dan kualifiaksi Guru dan Dosen belum pernah di evaluasi, walaupun gajinya ,lebih besar Guru atau dosen disbanding Ustadz/Ustadzah TPQ Qiro'ati. 
tahun. Salah satu ustadzah TPQ Qiro'ati Nasrul Ummah II, Desa Ngembalrejo, Kecamatan Bae Kudus bernama Istifaiyah, S.Ag mengatakan bahwa untuk memiliki syahadah memerlukan waktu 4 tahun, sama dengan masa perkulihannya di jenjang Sarjana (S1). Ustadzah lainnya bernama Ruaidah, S.Pd.I butuh waktu lebih lama dibanding Istifaiyah, S.Ag, yaitu mencapai waktu 5,5 tahun. Hal ini menandakan seriusnya proses dan kriteria seseorang ustadz/ustadzah untuk bisa dinyatakan layak sebagai ustadz/ustadzah di TPQ Qiro'ati.

Kedua, jumlah kelas atau rombongan belajar (rombel) ditentukan setiap satu ustadz/ustadzah mengajar maksimal 20 santri. Walaupun ditentukan setiap satu ustadz/ustadzah mengajar maksimal 20 santri, tetapi pada kenyataannya pengelola TPQ menekankan pada jumlah maksimal 15 santri. Hal ini diharapkan agar kualitas pembelajaran benar-benar dapat dijaga, dipertahankan dan dikembangkan. Ketiga, materi pembelajaran tidak hanya materi yang berkaitan dengan kemampuan baca tulis Al Qur'an melainkan meliputi materi yang berkaitan dengn kemampuan menjalankan nilai-nilai agama di dalam keluarga dan masyarakat. Selain diajari tentang baca tulis Al Qur'an, para santri juga diajari tentang berbagai bacaan dan hafalan do'a kehidupan sehari hari, kemampuan memimpin tahlil, dan etika dan kepribadian dalam bergaul kepada kedua orang tua, keluarga dan masyarakat.

Keempat, pencapaian ketuntasan penguasaan materi dilakukan dengan cara optimal dan sempurna, yaitu para santri dinyatakan naik atau pindah halaman jika telah benar-benar lancar membaca dan benar dalam mahrujul hurufnya. Sehingga tidak semua santri setiap hari bisa dinyatakan naik atau pindah halaman materi pembelajaran atau buku jilid qiro'ati. Kemampuan dan keterampilan santri dalam mempraktikan mahrujul huruf benar-benar menjadi indikasi untuk menyatakan santri layak dinyatakan pindah halaman buku jilid qiro'ati atau tidak.

\section{E. Pembinaan Kualifikasi dan Kompetensi Guru TPQ Metode Qiro'ati}

Kemampuaan dan kompetensi ustadz/ustadzah TPQ Qiro'ati selalu dipantau dan diawasi, apakah para ustadz/ustadzah benar-benar masih memiliki kemampuan dan keterampilan membaca dan menulis Al Qur'an atau tidak. Walaupun sudah mendapatkan syahadah dan dinyatakan layak sebagai ustadz/ustadzah, jika dalam kurun waktu tertenu setelah dievaluasi ternyata kemampuannya berkurang, maka diperlakukan berbagai langkah untuk membina. Jika setelah dilakukan pembinaan ternyata kemampuan membaca dan menulis Al Qur'an tidak ada perkembangan maka sertifikat yang sudah pernah diterima akan ditarik dan dinyatakan tidak layak menjadi tenaga pengajar di TPQ Qiro'ati.

Wawancara dengan KH. Halimi (Koordinator Materi TPQ) pada tanggal 12 April 2017 menyatakan bahwa pihak pengelola TPQ memiliki jadwal secara periodik untuk melihat, mengecek dan memantau kemampuan baca tulis Al Qur'an untuk semua ustadz/ustadzah yang ada di TPQ Qiro'ati. “ Begini Pak. Kami dari TPQ Qiro'ati itu memiliki tradisi atau aturan untuk memantau kemampuan BTQ bagi para ustadz/ustadzah disetiap jenjang, ditingkat kecamatan dan tingkat kabupaten bahkan ditingkat pusat, tujuanya selain untuk ajang silaturrahiim juga untuk memantau kemampuan para ustadz/ustadzah dalam belajar atau meningkat kemampuan BTQ”.

Pembinaan kualifikasi dan sekaligus kompetensi merupakan wujud nyata komitmen pengelola TPQ Qiro'ati dalam mempertahankan dan terus mengembangkan kualitas bagi para tenaga pendidiknya. Hal ini didasarkan bahwa kualitas tenaga pendidik memiliki peran sangat besar dalam melahirkan lulusan berkualitas. Forum pembinaan kepada para ustadz/ustadzah dilakukan secara formal dalam artian dilaksanakan secara terstruktur dan rutin. Dalam wawancara dengan KH. Mustain Yanis (Koordinator TPQ Tingkat Kabupaten Kudus) tanggal 16 Oktober 2017 dijelaskan "Forum yang dijadikan ajang untuk memantau mutu para ustadz/ustadzah bernama Majelis Mua'allimil Qur'an (MMQ) yang dilaksanakan secara rutin setiap bulan sekali dikuti semua Ustadz/Ustadzah TPQ Qiro'ti. Tempat berlansungnya MMQ 
berpindah pindah dari satu TPQ ke TPQ lainya. Materi MMQ menekankan kegiatan membaca al-Qur'an secara tartil, dari juz 1-30".

Berdasarkan data di atas, dapat dikatakan bahwa mutu dalam kualifikasi dan kompetensi para ustadz/ustadzah TPQ Qiro'ati benar-benar dilaksanakan secara optimal, utuh dan komprehensif. Optimal artinya target yang diharapkan tidak hanya cukup memenuhi standar yang ditentukan tetapi melampaui yang ditentukan. Utuh mengandung maksud mutu yang diharapkan tidak cukup hanya dalam satu aspek tertentu melainkan menyangkut berbagai aspek. Komprehensif berarti mutu yang diharapkan dilakukan oleh berbagai elemen.

Kualifikasi dan kompetensi para ustadz/ ustadzah TPQ Qiro'ati memiliki jaminan mutu yang dapat dihandalkan. Setidaknya dalam pandangan Suwito ${ }^{13}$ yang mengatakan bahwa mutu memiliki tiga hal yaitu, pertama, proses mengajak dan mengarahkan untuk mencapai tujuan yang diharapkan. Kedua, mutu adalah bagian dari komunikasi dengan berbagai elemen pendidikan, dan ketiga, mutu bagian dari gaya kepemimpinan dalam mengoptimalkan atau memberdayakan potensi yang dimiliki. Forum MMQ memiliki tiga makna mutu yang digambarkan oleh Suwito. Selain memiliki bentuk gaya kepemimpinan dan cara komunikasi yang khas, MMQ juga memiliki tujuan untuk mengajak dan mengarahkan agar kualitas bacaan dan tulisan para ustadz/ustadzah TPQ Qiro'ati benar-benar tetap terjaga dan dapat dipastikan dapat dikembangkan secara optimal.

Pendidikan Islam seperti TPQ Qiro'ati secara kelembagaan dan sosial memiliki tujuan sangat mulia yaitu ingin melahirkan lulusan (santriwan/wati) yang tidak hanya terampil dalam membaca dan menulis serta melafalkan doa-doa harian melainkan harus mampu melahirkan sosok manusia yang utuh baik dari aspek kecerdasan intelektual (kognitif), kecerdasan sikap kepribadian (afektif) maupun kecerdasan fisik/otot (psikomotorik).

M. Saekan Muchith ${ }^{14}$ dalam buku Isu-isu Kontemporer Pendidikan Islam menjelaskan bahwa pendidikan agama Islam harus melebihi pendidikan umum (non pendidikan Islam). Karena pendidikan umum secara normatif memiliki tujuan sangat mulia baik yang menyangkut aspek fisik maupun non fisik, oleh sebab itu pendidikan Islam harus melebihi target yang ditentukan oleh pendidikan umum. TPQ Qiro'ati akan memberikan bukti nyata bahwa dilihat dari aspek proses dan produk/hasil bisa melebihi target yang ditentukan oleh pendidikan di luar pendidikan Islam.

Kelebihan dalam berbagai aspek yang dimiliki TPQ Qiro'ati jika dibanding dengan pendidikan lainnya akan sangat mudah terwujud karena tenaga pendidik yang menjadi faktor dominan memiliki kualifikasi dan kompetensi yang selalu dipantau, diarahkan dan dikembangkan secara rutin dan sistematis. Profesi guru dan dosen yang memiliki ikatan dan kompensasi lebih besar belum memiliki aturan dalam pengawasan kualitas kompetensi secara rutin dan sistematis seperti halnya yang dilakukan dilingkungan TPQ Qiro'ati. Belum pernah ada forum formal yang memiliki kewenangan untuk mencabut sertifikat profesi pendidik (guru dan dosen) karena dinyatakan kompetensi pendidikannya menurun.

\section{F. Evaluasi (Ujian) bagi Santri TPQ Metode Qiro'ati}

Proses pendidikan memiliki tiga poros yang tidak bisa ditinggalkan yaitu Input, Proses dan Output. Kesempurnaan ketiga poros tersebut akan terwujud jika dilakukan proses evaluasi. Karena evaluasi merupakan proses untuk memberikan kepastian kualitas yang dimiliki lembaga pendidikan. Undang-Undang Sistem Pendidikan Nasional nomor 20 tahun 2003 Pasal 1 ayat 21 menjelaskan bahwa evaluasi adalah keegiatan pengendalian, penjaminan dan

\footnotetext{
${ }^{13}$ Suwito, Manajemen Mutu Pesantren, (Sleman Yogyakarta: Deepublish), 2015, hal. 15.

${ }^{14}$ M. Saekan Muchith, Isu-isu Kontemporer Pendidikan Islam, (buku Daros), tidak diterbitkan, STAIN Kudus, 2006, hal. 22.
} 
pemetaan mutu pendidikan terhadap berbagai komponen pendidikan pada setiap jalur, jenjang dan jenis pendidikan sebagai bentuk pertanggung jawaban penyelenggaraan pendidikan.

Dalam perspektif ilmu manajemen, evaluasi selalu diletakan di tahapan terakhir karena evaluasi berfungsi untuk mengetahui, memetakan dan mengendalikan mutu yang telah ditetapkan. Evaluasi atau disebut imtaz dilakukan dengan cara yang utuh dan komprehensif sehingga benar benar bisa melahirkan kualitas lulusan yang dapat dihandalkan. Sistem ujian (imtaz) bagi santri TPQ Qiro'ati memiliki perbedaan yang unik jika dibandingkan dengan system ujian lainnya. Berdasarkan wawancara dengan Kepala TPQ Nahrul Ummah II Desa Ngembalrejo tanggal 11 Juli 2018, diperoleh data bahwa proses ujian (imtaz) dilakukan dengan tiga tahap, pertama imtaz di tingkat lembaga yaitu ujian dihadapan Ustadz/Ustadzahnya sendiri, kedua imtaz di tingkat kecamatan dengan penguji koordinator TPQ tingkat kecamatan, dan sekaligus dilakukan pembinaan jika santri belum mencapai kriteria nilai yang ditentukan. Nilai minimal dinyatakan lulus jika santri memperoleh nilai 9 (sembilan). Bagi santri yang belum mampu meraih nilai 9 (sembilan) diberi kesempatan ujian tiga kali. Ketiga, imtaz di tingkat kabupaten (cabang). Pada tahap inilah yang menentukan apakah santri layak atau tidak diikutkan haflah (wisuda) ${ }^{15}$.

Proses ujian yang dilakukan dengan berbagai tahap dan dengan prosedur dan kriteria yang jelas dan kongkrit yang secara prediktif akademik akan mampu melahirkan lulusan yang berkualitas. Tahapan yang berjenjang dengan penguji yang berbeda dapat menjadi sarana penguatan kemampuan psikologis (mental) para santri. Selain tahapan yang berjenjang, materi ujian meliputi 8 (delapan) bahasan (bab) yaitu fashohah, tartil, ghorib Qur'an, tajwid, surat pendek, doa-doa harian, wudlu, dan salat. Selain tahapan yang berjenjang dan materi yang lengkap, proses ujian para santri juga bersifat terbuka (promosi) yaitu pada saat wisuda (haflah). Para santri yang dinyatakan lulus, pada saat haflah akan dites secara terbuka di hadapan forum. Peserta atau orang tua juga dipersilahkan ikut menguji dengan materi sesuai ruang lingkup 8 (delapan) bahasan tersebut. Oleh sebab itu kemampuan dan keterampilan santri dalam memahami materi akan sangat mudah diketahui oleh masyarakat.

\section{G. Pengembangan Kelembagaan TPQ Metode Qiro'ati}

TPQ Metode Qiro'ati tidak hanya berhenti pada proses pembelajaran baca tulis Al Qur'an secara benar dan tepat dari sisi mahrujul huruf (tafwid), melainkan berkembang kepada kemampuan menghafal Al Qur'an secara cepat, tepat dan benar dari aspek mahrujul huruf (tajwid). Menyiapkan kader akder penghafal Al Qur'an (hafidz/hafidzah) merupakan langkah strategis dan taktis di era globalisasi yang dikelilingi peluang manusia untuk melakukan kejahatan. Menghafal Al Qur'an bisa membentengi ahlak atau kepribadian manusia dari segala hal yang berpotensi merugikan dirinya sendiri dan masyarakat. Para penghafal Al Qur'an akan menjadi manusia yang sempurna di antara manusia lainnya. Sesuai sabda Rasulullah Saw "sebaik-baik kalian adalah yang mempelajari Al Qur'an dan mengajarkannya " (HR. Bukhari Muslim).

Kemuliaan yang diperoleh dari hafal Al Qur'an akan berimplikasi kemuliaan derajat dalam kehidupan dunia dan akherat. Oleh sebab itu setiap orang yang hafal Al Qur'an lebih

\footnotetext{
${ }^{15}$ Peneliti beberapa kali mengikuti atau melihat secara langsung proses haflah TPQ Qiro'ati yang dilakukan meirip dengan Ujian Promosi Program Doktor, bahkan dapat dikatakan melebihi ujian promosi doktor. Karena ujian Promosi Doktor yang bertanya hanya penguji yang berjumlah berkisat 7-9 orang penguji, sedangkan peserta yang hadir tidak diperbolehkan memberikan pertanyaan atau menguji. Dalam forum haflah (wisuda) TPQ Qiro'ati, masyarakat umum yang hadir di beri kesempatan untuk memberikan pertanyaan kepada santri yang menjadi peserta Haflah. Dapat dikatakan ujian atau Haflah TPQ Qiro'ati benar benar terbuka dan transparan. Terbuka berarti siapapun boleh memberikan pertanayaan, sedanagkan transparan adalah jika ada kesalahan lanhgsung dapat diketahui secara langsung saat itu juga.
} 
diutaman sebagai imam atau pemimpin suatu kaum (masyarakat). Sesuai sabda Rasulullah Saw, "Yang mengimami suatu kaum adalah yang paling banyak hafalan Kitab Allah. Kalau dalam bacaan (hafalan) itu sama, maka yang lebih mengetahui sunnah. Kalau dalam sunah sama, maka yang paling dahulu hijrahnya. Kalau dalam hijrahnya sama, maka yang paling dahulu masuk Islam. Dan jangan seseorang menjadi Imam atas saudaranya dalam kekuasaannya. Dan jangan duduk di tempat duduk khusus di rumahnya kecuali atas seizinnya”. (HR. Bukhari Muslim).

Hadis yang diriwayatkan oleh Amir bin Wailah dijelaskan "Sesungguhnya Nafi' bin Abdul Harits bertemu dengan Umar di Asfan. Dimana dahulu Umar telah mengangkatnya di Mekkah. Maka beliau mengatakan, "Siapa yang anda angkat untuk penduduk wadi (Mekkah)? Maka dia menjawab, "Ibnu Abza? (Umar) bertanya, "Siapa Ibnu Abza? Dijawab, "Diantara budak-budak kami. Berkata, "Apakah anda angkat untuk mereka seorang budak? Dijawab, "Beliau pembaca (penghafal) Kitab Allah Azza Wajalla dan beliau pandai dalam bidang ilmu Faroid (ilmu warisan). Maka Umar mengatakan, "Maka sesungguhnya Nabi kamu semua sallallahu alaihi wa sallam telah bersabda, "Sesungguhnya Allah mengangkat dengan Kitab ini suatu kaum dan merendahkan kaum lainnya." (HR. Muslim).

Akibat kemuliaan yang dimiliki setiap penghafal Al Qur'an maka dalam kehidupan sehariharinya akan ditemani para malaikat. Sesuai sabda Rasulullah Saw "Perumpamaan orang yang membaca Qur'an sementara dia telah menghafalkannya, maka bersama para malaikat yang mulia. Dan perumpamaan yang membaca dalam kondisi berusaha keras (belajar membacanya) maka dia mendapatkn dua pahala.' (HR. Bukhori Muslim). Begitu besarnya keunggulan manusia yang hafal Al Qur'an maka TPQ qiroati memiliki komitmen untuk melakukan pengembangan kelembagaan dengan tujuan untuk mengembangkan kemampuan baca tulis Al Qur'an para santri. Artinya para santri yang sudah lulus dari TPQ Qiro'ati harus memiliki semangat untuk mengembangkan kemampuan pengetahuan dan pemahaman tentang Al Qur'an.

Pengelola TPQ Qiro'ati memberikan kesempatan dan fasilitas kepada para lulusanya untuk mengembangkan kemampuan dan ketrampilan mengetahui, memahami dan mengaplikasikan Al Qur'an. Berdasarkan wawancara dengan Koordinator TPQ Qiro'ati Tingkat Kabupaten Kudus (KH. Mustain Yanis Al Hafidz) pada tanggal 16 April 2017 dijelaskan bahwa TPQ Qiroa'ti yang menekankan pada ketrampilan baca tulis Al Qur'an bisa dikembangkan menjadi penghafal Al Qur'an (hafidz) tanpa harus mondok (meninggalkan rumah) dalam waktu tertentu.

"Begini Pak.. kalau selama ini masyarakat beranggapan, kalau anaknya ingin menjadi hafidz atau penghafal alqur'an itu harus mondok atau meninggalkan rumah sampai bertahun tahun. Lha.. TPQ Qiro'ati ingin memberikan bukti bahwa manyarakat yang ingin menjadi hafidz tidak harus meninggalkan rumah dalam kurun waktu tertentu. $T P Q$ Qiro'ati dengan metode yang dimiliki bisa memberikan jaminan, anak anak bisa hafal Al qur'an dengan tetap bisa sekolah formal, bisa tetap membantu pekerjaan orang tua di rumah".

Program pengembangan TPQ Qiro'ati bernama Pasca TPQ Tahfidz atau disingkat dengan TPQT dan pascaTPQ Diniyah atau disingkat TPTD. TPQT dan TPQD ini melaksanakan metode pembelajaran yang bisa menjamin para santri bisa hafal Al Qur'an dalam waktu yang relatif singkat. TPQT diwujudkan dalam pendidikan formal (sekolah) bernama SD Qiroati dan SMP Qiroati yang memiliki perbedaan dengan SD dan SMP selain Qiroati. Perbedaannya dengan lainya, SD dan SMP Qiroati memiliki pelajaran yang sama dengan SD dan SMP lainya, pernbedaanya SD dan SMP Qiroati pada saat lulus memiliki target hafal Al Qur'an denagn jumlah juz tertantu. Jika sekolah di SD dan SMP Qiroati selama 9 tahun, maksimal dapat dipastikan sudah hafal alqur'an sebanyak 30 Juz. Pada usia 15 tahun 
jika anak disekolahkan di SD dan SMP Qiroati dipastikan sudah menjadi penghafal Al Qur' an dengan tidak harus meninggalkan sekolah formalnya.

Bagi masyarakat yang tidak senang dengan sekolah formal, maka TPQ Qiroati menyediakan bentuk pendidikan nonformal bernama Diniyah, yaitu lembaga pendidikan di bawah pengelolaan Qiro'ati yang menerima para santri lulusan TPQ Qiro'ati dengan penekannya menghafal Al qur'an dalam waktu 3 tahun atau setara dengan SMP/MTs. TPQ Qiro'ati merupakan salah satu lembaga pendidikan Islam di Kabupaten Kudus Jawa Tengah yang bisa menyakinkan masyarakat tentang kualitas proses dan hasil pendidikan, karena mampu memberikan tawaran dan sekaligus bukti TPQ Qiro'ati benar-benar menjunjung tinggi dan berkomitmen terhadap mutu pendidikan. Hadirrnya TPQ Qiro'ati dalam pandangan Abuddin Nata ${ }^{16}$ disebut sebagai proses mendeteksi, dan mengatasi semua kelemanahan atau penyakit umat Islam.

Dari sudut pandang realitas obyektif, umat Islam memiliki banyak kekurangan yang harus segera diselesaikan melalui jalur-jalur pendidikan informal, formal dan nonformal. Kekurangan yang mendesak dihadapi menyangkut tentang cara pandang atau pemahaman dan aplikasi nilai-nilai ajaran Islam ke dalam realitas kehidupan sosial. Muchith ${ }^{17}$ berpendapat bahwa akar persoalan umat Islam seperti radikalisme diawali dari pemahaman nilai-nilai agama yang bersifat tekstualis seperti perintah perang (QS Al Baqarah :193), perintah memerangi atau membunuh orang kafir (QS. Muhamad : 4), perintah memerangi kepada orang orang yang tidak beriman (QS.at Taubah : 29).

Berbagai kekurangan atau kelemahan yang dimiliki masyarakat harus diselesaikan melalui jalur pendidikan. Dengan asumsi sistemik, pendidikan adalah proses menjadikan manusia lebih sempurna secara fisik dan nonfisik (lahir batin). Salah satu hal yang tidak boleh dilupakan dan dihilangkan dari proses pendidikan adalah terwujudnya budaya perusahaan (company culture) yaitu proses membangun sistem nilai, kepercayaan dan kebiasan secara terus menerus yang meliputi persoalan intelektualitas, sikap kepriabdian (moral) dan perilaku atau tindakan. Kualitas yang utuh dari pendidikan menyangkut tentang persoalan tradisi atau budaya kehidupan manusia yang meliputi cara fikir, sikap, tindakan, produk pemikiran dan juga produk ketrampilan fisik (artifax).

Syahu Sugian ${ }^{18}$ mengatakan Total Quality Mutu (TQM) adalah realitas budaya yang dimiliki suatu perusahaan yang berkaitan dengan system nilai, kepercayaan dan keyakinan serta kebiasaan baik yang melekat secara terus menerus dalam diri karyawan.

Proses pendidikan yang dilakukan TPQ Qiro'ati mulai dari perencanaan sampai dengan output dan pengembangan kelembagaan akan mampu melahirkan sosok kepribadian manusia secara utuh dalam aspek fisik maupun nonfisik. Dengan berbagai tahapan yang cukup ketat, maka pendidikan Islam seperti TPQ Qiro'ati akan melahirkan manusia yang berfikir besar, berjiwa besar dan berorientasi jauh ke depan untuk membangun masa depan. Indonesia memerlukan para pemimpin dan warga masyarakat yang tidak saja memiliki pengetahuan tetapi benar-benar mampu mengamalkan nilai nilai yang di ambil dari realitas kehidupan masyarakat.

Pendidikan Islam sekurang kurangnya memiliki 4 (empat) aspek yang tidak boleh ditinggalkan yaitu aspek transcendental, rasional, moral dan teknologi. Sebagai perwujudkan

\footnotetext{
${ }^{16}$ Abuddin Nata, Manajemen Pendidikan: Mengatasi Kelemahan Pendidikan Islam di Indonesia, (Jakarta: Kencana), 2012, hal. 377.

${ }^{17}$ M. Saekan Muchith, "Radikalisme Dalam Dunia Pendidikan" Jurnal Addin, edisi Februari, STAIN Kudus Jawa Tengah, (2006). hal. 171-172.

${ }^{18}$ Syahu Sugian, Kamus Manajemen Mutu, (Jakarta: PT Gramedia), 2006, hal. 231.
} 
bahwa pendidikan adalah proses humanisasi, maka empat hal dalam pendidikan harus selalu melaket dalam proses dan hasil ${ }^{19}$.

\section{H. Penutup}

Total Quality Manajemen (TQM) yang dipahami oleh para pengelola TPQ metode Qiro'ati, tidak hanya bersifat fisik dan nonfisik melainkan lebih ditekankan kepada kepuasan atau kepercayaan dari masyarakat.Terwujudnya TQM di TPQ Qiro'ati didukung dengan besarnya perhatian para pengelola terhadap kompetensi dan kualifikasi para ustadz/ustadzahnya, proses ujian (imtaz) sehingga bisa meningkatkan kepercayaan dari masyarakat. Hal ini bisa dilihat dari semakin bertambahnya pendaftar masuk ke TPQ Qiro'ati setiap tahunnya. TQM juga dilakukan melalui pengembangan kelembagaan berupa SD, SMP dan metode Qiro'ati dilakukan dengan tetap mempertahankan dan meningkatkan kualitas lanjutan mutu yang telah ditentukan dari TPQ sehingga TQM benar benar terwujud secara utuh dan komprehensif.

\section{DAFTAR PUSTAKA}

Azra, Azumardi. Pendidikan Islam: Tradisi dan Moderenisasi Menuju Milenium Baru, Jakarta: Logis Wacana Ilmu, 1998.

Crosby, Philip B. Quality is Free, USA: New American Library, 1980.

Deming, Edward W. Out of the Crisis: Quality, Productivity and Competitive Position, Cambridge: Cambridge University Press, 1986.

http://www.Qiro'atipusat.or.id, diunduh pada tanggal 21 Juni 2018.

Juran, Joseph M. Quality Handbook, New York: McGraw Hill, 1988.

Marimba, Ahmad D. Pengantar Filsafat pendidikan Islam, Bandung, Jawa Barat: Maarif, 1989.

Moleong, Lexy J. Metode Penelitiaan Kualitatif. Bandung Jawa Barat: PT. Remaja Rosdakarya, 1995.

Muchith, M. Saekan. Isu-isu Kontemporer Pendidikan Islam, Buku Daros tidak diterbitkan, Kudus: STAIN Kudus, 2006.

Muchith, M. Saekan. "Radikalisme dalam Dunia Pendidikan" Jurnal Addin, edisi Februari, STAIN Kudus Jawa Tengah, (2006).

Muchith, M. Saekan. Kepemimpinan STAIN Kudus Berbasis Filosofi Laut, STAIN Kudus Press, 2017.

Nasution, S. Metode Penelitian Naturalistik Kualitatif, Bandung Jawa Barat: Tarsito, 1992.

Nata, Abuddin. Manajemen Pendidikan: Mengatasi Kelemahan Pendidikan Islam di Indonesia, Jakarta: Kencana, 2012.

Peraturan Pemerintah (PP) Nomor 55 tahun 2007 tentang Pendidikan Agama dan Pendidikan Keagamaan.

Salis, Edward. Total Quality Management, Daerah istimewa Yogyakarta: Ircisod, 2007.

Sugiyono, Metode Penelitian Pendidikan, pendekatan Kuantitatif, Kualitatif dan R\&D, Bandung Jawa Barat: Alfabeta, 2008.

Suwito. Manajemen Mutu Pesantren, Sleman Yogyakarta: Deepublish, 2005.

Sugian, Syahu. Kamus Manajemen Mutu, Jakarta: PT Gramedia, 2006.

Undang Undang Sistem Pendidikan Nasional (UUSPN) Nomor 20 tahun 2003, Pasal 1 ayat 1.

${ }^{19}$ M. Saekan Muchith, Kepemimpinan STAIN Kudus Berbasis Filosofi Laut, (Kudus: STAIN Kudus Press), 2017, hal. 8-9. 